\title{
The Cognitive Problem of the Behavioral Decision Theory Through Game Theory: Biases and Heuristics
}

\author{
Alexandre Morais da Rosa \\ Universidade do Vale do Itajaí
}

This paper examines an alternative approach to the analysis of decision-making under the lens of Game Theory. To do so, this text seeks to demonstrate through the inductive method that this bias is capable of providing the necessary instruments for a better understanding of judicial decisions, distancing itself from the usual once the approach is modified. It deals with the problem of decision theory regarding the lack of explanation about how decisions are produced in order to stimulate the dialogue and the application of multidisciplinary content, reflecting the theoretical-practical concern in indicating the correct form of procedural rationality. Faced with literature review, this paper highlights the evidence that the introduction of game theory to the process is able to improve the procedural reading in an uncertain environment. In this context, the understanding of heuristics and biases through game theory makes it possible to realistically establish the structure of human interactions mediated by the process. The relevance of this issue is the repercussion of judicial decisions on social and procedural relations as a whole.

Keywords: decision theory, game theory, judicial decision, judge, biases, heuristics

\section{INTRODUCTION}

The challenge of decision-making in the field of Law is the responsibility of all involved and there is no ex ante mandatory decision-making behavior. Based on evidence and normativity, whose meaning can vary without being previously given, accommodating different plans will be necessary: a) normative; $b$ ) interactional-cognitive, and c) contextual. This is because decisions must take into account the normative apparatus as well as the cognitive capacities of each of the players who participate in the procedural interaction, situated in time and space; that is, in a context ${ }^{1}$. With this preliminary assumption, it is possible to explore the possibilities of the judicial decision of the Brazilian legal world whose assumptions are constantly changing due to the various thinking matrices, especially the American model ${ }^{2}$. At the same time, a path to new argumentative perspectives opens, taking into account that it is subject to cognitive traps, understood as systematic errors (biases) and/or mental shortcuts (heuristics).

In each decision, mental accounting is carried out without sufficient time or qualified information in sufficient quantity to decide in a perfect way, and in many situations, there is no patience, willingness, or positive attitude on the part of the operators. Therefore, the decision-making process taught in Law school is callow,over-simplified, and not realistic.

It is worth emphasizing, in the context of this paper, what is being done and not what one says should be done, because the vast majority do not know how to say what needs to be done because they simply do 
not know how to do it. In general "decide just by deciding" is a process that involves using previous models, analogies, common places in deriving decisions. So it does not matter how they decide because it will be necessary to know how they decide in each scenario by an external look organized by the Game Theory. The chain of indicators needed for a decision varies widely, which is why we cannot be sure since there are multiple combinations. However, some understandable steps can be taken, which improve predictability and behavioral expectations in the decision-making process. From these premises, it will be impossible to present a single model of understanding, which is why it will always be necessary to establish the context of the decision and its actors.

The inductive method was used for both the investigation phase and the research report phase. The procedural method used was the monographic method and the research technique was the bibliographical research method.

\section{THE STANDARD DECISION MODEL DOES NOT EXPLAIN HOW DECISIONS ARE PRODUCED}

Decision-making is a human activity and it happens all the time, especially in Law, which is considered a specific activity in which a third party (alone or collectively) deliberates on a controversy posed in a technical and contradictory way. In addition to the normative plan and the personal circumstances, it is constructed before the antecedent experience, shortcuts of decision, standards, and beliefs about what "the better solution" is. It would be impossible to live without mental shortcuts, which are called "Heuristics", and make life easier. This can also lead to "Biases" (systematic errors) ${ }^{3}$. Therefore, it will be necessary to open the field of law for new knowledge that points out the importance of the influence of new factors in legal decision-making. In the juridical field, there is an overlap of the way one decides, with the influence of several variables, among them, emotional, intuitive, biological, etc. Thus, the standard model of mere subsumption is callow, since it does not sustain the complexity of the decision-making act. The cognitive trap is perfect because most lawyers say they act this way, though in most cases they do not have an adequate understanding of what is being done. This is because in the process of attribution of meaning, all human factors - emotional, biological, cognitive, ideological, etc. - may apply.

The decision theories are so complex and anti-intuitive that only a few take them seriously. The most interesting part is that theoretical common sense $e^{4}$ establishes models incapable of demonstrating the application in practical cases that they operate. The decision theory needs to demonstrate its usefulness in solving concrete problems in order to avoid discouraging and frustrating the actors who cannot verify its applicability. To do so, it must be intuitive and demonstrate that it can improve the daily life of the player 5 jurist. Involving operators presupposes engagement in something that makes sense and operates at the level of personal fulfillment (reward) of legal tasks. The quality of action feedback will be critical to the recognition of useful decision-making activity. It will be necessary, then, to understand how the jurists' attitudes and behaviors are decided, establishing a feasible operational framework.

Hence, the need to expand the coordinates of meaning to make the experience with the judicial decision more feasible and realistic, always looking for novelties that could broaden the realistic way in which a criminal decision can occur. The result is the establishment of practical indicators, conjugated with theoretical discussion, having as a research field the behavioral economy, memory, and brain functioning. This is because, depending on how interaction occurs, on patterns of behavior and reasoning, the quality of the individual and collective results can be improved.

The models of decision-making common in Law still operate with the logic of subsumption - that is of the major premise deduced from the law and the minor premise arising from the facts found, which, through reasoning, could lead to a logical conclusion. Manuel Atienza ${ }^{6}$, at the level of argumentation, describes and then criticizes the distinction between the context of discovery and justification. It is also accepted, among others, by Habermas ${ }^{7}$ and it is considered as arbitrary and makes legitimate the outcome of the decision and not its course. But also, he underlines the importance of the auditoriums in which discourse is articulated ${ }^{8}$. In the case of the procedural game, the judges are the audience, whether they want 
it or not. Therefore, a topic dedicated to the subject of perception, heuristics, and biases, with emphasis on the aspects that can "steal the spotlight" (conscious and unconscious).

In any case, this model that fits the decision makes room for what John Kay calls the "Franklin's gambit" in honor of the prominent Benjamin Franklin, according to whom, "So convenient a thing it is to be a reasonable creature since it enables one to find or make a reason for everything one had a mind to do" ${ }^{\text {". This is because retrospective reading }}{ }^{10}$, after the conduct has been performed, provides traps of cognition and narratives (retrospective heuristics). The ability of players/judges to articulate the time, chronology, and sequence of information may yield mixed conclusions. But it is known in advance that explaining later is easier cognitively.

The retrospective bias makes it possible to articulate a minimally coherent and consistent version of decisions (even when they are not). The problem is that the construction of the reasons is backward; that is, from the present to the past, which ensures that it can be justified (rhetorically or by manipulating premises and facts). What is done is not to narrate the decision process from the past to the present, but the reasons established after the event. This is called "retrospective bias". ${ }^{11}$ The retrospective narrative, explored by legal argumentation, can have linearity effects and evident anticipation of results that, in reverse order (from the present to the past), would not be so clear. The retrospective bias in the criminal procedural game is powerful and as such gives the impression that one can more easily conceive cause and effect relationships, though the world is much more chaotic than can be articulated. There is a focus on several variables capable of constructing convincing argumentation or not, especially fallacies. The way an argument is constructed will make a difference in the cognitive map of the process.

The stance that treats theory as reality and reality as a mistake, not of theory, but its own, persecutes the jurist who finds himself/herself in the paradise of concepts. Linking one concept to another, in spite of facticity, many jurists shrug off the facts tied to the world of "conceptual paradise" that the Vienna Circle inspired $^{12}$. The complexity of the world and the (im)possible reconstruction within the limits of the judicial process are taken by factual references devoid of facticity. The deontological forecasts, by which it is possible to prohibit, authorize or oblige conducts, although they serve as beacons, never predict the future. It would be wonderful if a prediction could be possible this way. But precisely because the world is more complex than legislative statements, the claim is imaginary.

The problem is actually believing or pretending, more cynically, that it is possible to respond exclusively on the basis of norms. This position is not adopted in a fraudulent way by most jurists. It is part of their way of being. After all, the jurists were taught this way. And when one begins to question the way one thinks, often, one enters into despair or closes himself/herself off from what he/she believes. This dictum intends to discuss precisely the way in which one has been taught to find a juridical reason for everything, especially in the current "pan-principialist" universe in which a principle ends up destroying a possible expectation of behavior of the interpreter. ${ }^{13}$

\section{THE GAME THEORY AS THE FORMAL MATRIX OF DECISION}

The process is a competition among diverse players with different rewards and the primary vision is that if each one pursues his/her individual interests, the result of their actions will be better well-being (Adam Smith ${ }^{14}$ ). Thus, players end up looking for the best strategy without realizing that cooperation is a major factor. They create duels, rivalries, and unceasing struggles for conviction without realizing something obvious described by John Nash: collective well-being will be best when you do the best for yourself and the group.

Since the process is metaphorized by the Game Theory, it can be seen that the struggle for victory must come from the proper reading of the context of the game, in which the interaction depends on the rules known to the players, especially the magistrates (where the decision power of the controversy is applied), the possible rewards, and the tactics and strategies used. The official resource provided by the Game Theory can be a powerful cognitive advantage in expanding performance and detecting errors and accuracy. All this takes into account that the process does not always operate with rational players and that the more one knows the way they think - the Mind Map, understood as the set of individual cognitive assumptions - the 
more one will be able to predict procedural behaviors and adjust tactics and strategies. Finally, these are tactical-strategic interactions between human beings located in time and space, with a dynamic character; that is, they can change at any time.

The Game Theory will serve as a metaphor for the process in which the probative letters (existing and can be produced) must be inventoried, strategically thought and know how to play, combining the cognitive, argumentative and technical aspects. It presupposes the knowledge of the normative apparatus and its multiple possible meanings. One should study not only the authors (indoctrinators) and/or Courts that one likes but also those that one does not like because this could be what the judge will receive, and it is him/her that you need to convince. One cannot convince someone with decision-making power without understanding the respective arguments.

The challenge of the interaction resides in the possibility of elaborating the theory of the $\mathrm{mind} / \mathrm{brain}^{15}$ of the other players; that is, the theory and evidence of how others that interact with us think and behave. This becomes evident when we get to know the family, friends, and children since, with the volume and quality of background information, it is possible to predict what they will do or how they will behave with a greater or lesser degree of accuracy. Therefore, if it is possible to take seriously the people with whom one interacts, one should also know that "I think He/She thinks that I think that He/She thinks" to infinity. Without this step towards cognitive interaction, the process studied and taught remains in the normative field of the jurists. Those, end up sliding in the imaginary of the single jurist, complete and coherent, who doesn't exist.

The most common cognitive trap is that one is capable enough to enter the minds of other players and anticipate tactical actions, without due course and a certain amount of doubt. This is mainly because he/she fails to recognize the assumption: players who interact do not think in general as we think they think and it is very common to think that the other player would think as "we want" him/her to think. This is a basic and very common error in the process environment reported by the Game Theory. Knowing that one can look for pieces of evidence and indications presupposes that there is a different element in the other. This fundamental (and radical) difference needs to be taken seriously, otherwise the fundamental role of human interaction will not be understood. Thus, knowing the other players, their heuristics, and biases is a condition for predicting the least dominant and expected behavior. But this does not guarantee absolute certainty and a certain dose for the unexpected must always be expected.

The Game Theory makes it possible to establish dominant/neutral/dominated behaviors in the face of the possible actions of the other players who are interacting. If it is possible to anticipate what the tactics and strategy of the antagonist or even the judge will be, one's cognitive ability will improve and one can operate in accordance with the strategy with greater accuracy. Losses and mitigating risks are minimized and the right course of action is followed.

In this way, we must also know that one can be a victim of his/her own heuristics and biases, among them overconfidence ${ }^{16}$. Therefore, it is fundamental to accept the complexity and uncertainty of the huge chains and decision nodes that can, in one way, change the entire strategic course. The proposed interaction will be among the players, with psychological and biological aspects that change within each decision context, taking into consideration the behavioral aspects.

The course is somewhat different because it does not matter, as it reaffirms what jurists say they do, but rather the volatility with which they make decisions, proposing a broader concept of rationality in which apparent irrationality (emotions, anger, rancor, love, jealousy, etc.) is understood and used in the decision matrix. Put more directly, the notion of modern reasoning cannot account for complexity. Rationality is not ruled out, although without betting all chips on it, the Game Theory is considered the matrix of decisionmaking ${ }^{17}$.

Far from being a joke, the notion of game is used in a large philosophical, economic, and law bibliography, among other fields, precisely in the sense that Game Theory provides a situation contextualized in space and time in which rational agents - players - behave (or should behave) strategically. The operability of the games, in turn, overcomes prejudice, often associate with Christian ideals (St. Thomas Aquinas considered game/gambling as a dangerous activity ${ }^{18}$ ), of having the game as something dirty and synonymous with a "prank" because of bets on people who understand interaction 
games as a serious part of life in society ${ }^{19}$. Incidentally, Colas Duflo ${ }^{20}$ demonstrates the use of the notion of game in authors like Thomas Aquinas, Pascal, Leibniz, Kant, Schiller, among others. Gadamer ${ }^{21}$ even says that "The first evidence we need to take into account is that playing is an elementary function of one's life, at such a level that human culture, without an element of play, is unthinkable". The modern erasure is that it can be redeemed at the moment. It is a formal bet of reading the structure of the game, always subject to the uncertainty of (ir)rational human interactions. The new point of view - from the Game Theory causes a certain repulsion because it apparently breaks the tradition of "seriousness" of work in the process field. The proposal is to take the human interaction seriously, without having something jocular, playful, or even abusive.

The subject has already been approached, directly or indirectly, by several authors, even recently ${ }^{22}$, emphasizing the classic text of Calamandrei ${ }^{23}$, in which he had stated that memorizing the rules of chess does not make the subject a great chess player. ${ }^{24} \mathrm{He}$ also stated that knowing the procedural rules does not make him/her a great procedural player; however, it is not possible to play without knowing the rules. Understanding dogmatism critically is important for anyone who wants to become a great player or judge. Robles $^{25}$, on the other hand, maintains that Law is comparable to the games since in both appear behaviors of cooperation, competition, fight, and conflict, in which the result does not depend only on luck but on the performance of the players in the face of Jurisdiction and behavior of procedural agents.

The following expression is often used: what is at stake $e^{26}$. Then, without abusive academic puritanism, of theories of low realistic factor, there is an aim to indicate "how" the process will work. This is because there are so many variables the composition of a procedural scenario depends on, such as a formal instrument capable of organizing the way the process is structured: The Game Theory. It is not enough to memorize the procedural rules because the process is an instrument of power in which the best players can make a difference. It is not a matter of merely applying/assembling legal rules to facts. The rules must be upheld by players who play fair, within fair play, although any of the players can always risk playing dirty to win. And this happens many times.

The ability to understand makes it possible to anticipate illegal/illegitimate moves so that one can create/invent coping tactics. If the procedural game is a human interaction regulated by the State that determines the manner in which the decision can be applied, from characters (judges and parties), with functions of varied content - given the plurality of meanings and attitudes of each place due to the normative scheme - the Game Theory, understood as an instrument for the formal analysis of conflicting interactions, can be used as a device for comprehension. The intended outcome of each player depends on the strategies and tactics chosen by each of the interaction agents. Therefore, anticipating the point at which there is stability in the face of strategies — that is, the Nash equilibrium (not always desired or existing ${ }^{27}$ ) — is the challenge in every singular procedural game.

There is a trajectory between the normative text and the meaning attributed by the players in each singular procedural context. The normative design of the abstract device present in the legislation may be far from the effective design, namely, the incident in that procedural interaction, hence the importance of mapping players and knowing who will have the power to establish valid rules - hidden games. Although expectations of normative behavior exist, it can be recognized as a "Babel of meanings" 28 , whose anticipation can only be realistic if the mind map (previous decisions, ways of operating and understanding, for example) and the rewards of real/effective players are considered in advance. Anyone who can exercise procedural powers in the procedural game, such as judges, parties, lawyers, witnesses, experts, media, etc., is considered a player. The plurality of competing meanings in the face of the same normative text implies an acknowledgment that there is no way to state surely what attributes and meanings will appear at the peak of procedural interaction. The complexity of the variables that can modify the destinies of procedural games lacks, in general, a theoretical grid capable of sustaining the reading of possible and attributable meanings in each procedural context. The Game Theory emerges as an attempt to integrate a set of conceptual tools that authorize the reading of the real games not only by the normative character but especially considering aspects linked to the creative performance of the players, influenced by individual rewards (democratic or not). 
Playing in a situation of plurality of non-shared meanings, thus, demands a practical approach that uses a formal theoretical framework, organizer of the game design in two moments. In the first, the possible meanings are articulated in the face of abstract normativity, and in the second, the tendency of real players is anticipated in the face of multiple possible behaviors.

The theoretical framework of Game Theory will be formal and, as such, does not respond to how the process should be precisely because it is linked to human interaction subject to the imponderable exercise of power. Although the claim of the legal norm is to limit arbitration, it is known that the legal text cannot account for the multiple realities, whose protagonists will be subjects located in time and space, linked to the maximization of their gains in each case.

The cognitive and communicational device enlivened in the process will be built by constant human interactions, open to collaboration and foul play, depending on the players' tactical and strategic choices. Faced with success in each sub-game (stage of the procedural rite), the elected tactic can bring forth basic pleasures that drive satisfaction, especially when playing through masks attributed to pre-defined places of inglorious struggles of good versus evil and vice versa. Many players will protect themselves by building a public avatar capable of mitigating, perhaps, the real danger.

The description of the possibilities of normative meaning and behaviors indicates what the players can do, with or without respect to the rules, as well as what they must do from a democratic standpoint. Dominant/dominated strategies can be established from the criteria of individual rewards. Overcoming the reductionist vision of real games as moments of dilettantism, with a combination of aesthetic, ethical, and democratic dimensions may imply new meanings for the criminal procedure in relation to effective procedural behavior.

The bias of self-fulfilling prophecy works here: if you think the game is a joke, you will not take seriously what is articulated next, even if you understand that Game Theory helps in reading human interactions linked to maximizing individual gains and the new horizons that open up. The challenge posed is complex and depends on the capacity of intelligence, preparation, and performance mainly because the imponderable can appear just when the individual least expects it. Always!

The formal reading of the procedural device will depend on the various concepts adopted by real players, full of multiplicity. Therefore, it is not possible to previously establish the content of the various procedural institutes which may follow different paths during the interactional course. What matters is that there is interaction through the contradictory. Provided with multiple theoretical perspectives (i.e., crime theory: finalists, objective imputation, etc.), the professional player will be able to operate on the normative board and in the field of real interactions, and thus better understand and anticipate dominant/dominated tactics/strategies in each procedural context.

Each procedural game, in its singularity, constructs convergent/divergent meanings compared to the collective standards described by the prevailing paradigm. The normative platform of the game suffers the human contingencies of the players, eager for the satisfaction of their rewards. The individual's understanding of the place and function of the criminal process alter the meaning of procedural play. The assumption of a place and function of guarantee of the collectivity, guarantee of the accused (individual) or both, as the premise, modifies the understanding of procedural norms.

What is intended in the proposal is to promote conditions for reading the gameplay, within and outside the established rules, mainly in the context of ambivalences of meaning that can be established before the possible rhetorical manipulation of normative texts. We can suggest "how to generically do" a tactic and/or strategy, without being possible, however, to previously indicate an adequate income in all cases. The construction of the criminal case theory in its uniqueness should be the first step. Only then will it be possible, in each specific context, to choose dominant/dominated tactics/strategies. In any case, aware of the design of the game, one can act more efficiently, given the concurrent reading between theory and practice, in order to identify the pattern of that game. Structuring the tactics/strategies will be a constant challenge that does not end a priori because it demands the continuous and dynamic work of strategic realignment, given the significant change in time and space, of the ongoing processual interaction.

Aware of the multiple possibilities of assigning meaning to procedural and penal norms, as well as knowing the mind map of the characters with a significant function in the singularized process, one can 
establish a shared vocabulary of meanings (not necessarily what one wishes, but what is possible). It is through the vocabulary and the meanings of the other procedural agents that one can, minimally, dialogue. The conceptual isolation of the institutes generates an unproductive clash of meanings in which the work of preliminary conviction may require inglorious and irrelevant effort. Dominating how the adversary and the judge think represents a communication gain. The argumentative territory of the procedural game must be shared in order to avoid talking to a wall, without any impact on the cognitive capture of the rest of the interaction agents.

\section{COGNITION, HEURISTICS, AND BIASES}

The vast majority of players (magistrates, lawyers, parties, etc.), although they make repeated procedural decisions (theses, questions, procedural decisions, etc.), have never had any technical and adequate training on the decision-making mechanism. Knowledge was acquired through experience, always limited, within their universe of performance, by the examples they had during their professional career and academic training without studying the cognitive, psychological ${ }^{29}$, emotional, regulatory, biological, and unconscious mechanisms that can (potentially) appear in the decision-making moment. Hence, it is necessary to understand minimum concepts arising from the procedural interaction that happens in an environment of uncertainty and information asymmetry; that is, always with less information than necessary for a perfect decision. Therefore, the decision will always be a bet on the best result, given the multiple factors involved in anticipating the consequences of the actions and effects of dominant/dominated tactics/strategies, especially in the field of contemporary law in which multiplicity of meanings and ambiguity prevail.

How can one know if strategy (what is intended with the procedural game) is adequate with the tactic (action or intermediate procedural behavior), in the face of the rewards of the other players? How should one behave in an increasingly complex, multidimensional process, full of ambiguity and uncertainty? To what extent can one realize and expect rational or irrational behavior? What are the external clues for proper reading of the singular procedural game; that is, the game that is being played?

From these questions, the intention is to move from the introduction of the Game Theory to the process. Perhaps, we can better situate ourselves in an environment of uncertainty, of (ir)rational choices that are increasingly present and that modify the possibility of reading the design of the procedural game. In any case, information management and behavior expectations gain an ally in the face of current cognitive difficulties. The study will be briefly carried out in two stages: (i) descriptive analysis of the behavior of procedural players, and: (ii) prescriptive analysis of how to improve the way issues are handled. Ways of understanding the underlying processes of decision-making in the procedural game will be suggested.

The theoretical-practical concern is to establish tools capable of indicating how to make certain decisions in the process. What are the criteria to avoid foreseeable errors and choose dominant/dominated tactics/strategies; that is, how to evaluate the effects of procedural actions? In an increasingly flexible and uncertain process, in which the coordinates of action change in the face of real players and contexts (and their rewards), risking the design path of game theory may be more realistic, especially in the face of the errors of our limited cognitive ability ${ }^{30}$. Hence, it is a different way of understanding the decision-making mechanism from multiple levels of approach, given that players are human subjects with limited rationality and strong emotional variable. Emotion and intuition are relegated by the silence of official discourse, although they operate at every moment of decision-making. Cognitive fluctuations play with several limiting factors, although by the fact that one thinks, it is usually believed, with overconfidence ${ }^{31}$ that dominates all the reasons and emotions of choices, as if it were possible to be omniscient of all the surrounding contexts. The effects of heuristics and biases are suffered.

Due to our limitations, it is necessary to understand a little of Cognitive Psychology. As we cannot and do not even have the capacity, disposition, and incentives - study, register, reflect, and decide in every situation of the (legal) world of life, heuristics (mental shortcuts) are created, which can lead to biases (systematic errors ${ }^{32}$ of thinking). Heuristics are simply shortcuts: intuitive and immediate judgments, devoid of reflection, based on experience (personal or consulted), capable of promoting decisions based on 
assumptions - partial knowledge. Our working memory is finite, the time of sparse reflection and the tendency to reduce mental effort a human reward. This is because we process environmental information and evidence within human limitations and we need, in order to reduce effort, to create pre-ready decision mechanisms since we are not always interested enough (there are not enough rewards) for us to pay attention (especially in repetitive cases or because of cognitive dissonance) to frequently generate patterns of decision-making behavior. Heuristics decreases the mind workload we handle during the day $^{33}$. It generates comfort, apparent coherence, but it can be a cognitive trap. In times of speed and efficiency in numbers, it seems to be fully operable.

This "facilitation" model is not restricted to players who may already have prior understandings of important themes and are not available for new arguments, as it happens, for example, with the summation logic of comfort or cognitive dissonance. If the subject is already decided, many do not accept the summation entry by reflection, but by mere adhesion. There is no reflective path when the destination point is already given. Hence, this is why heuristics was created: "mantras of meaning", adages, common places, informal, intuitive, and speculative tactics that can generate patterns of correctness and also of error ${ }^{34}$. In short, in the case of Law, they are mental shortcuts by which the complex decision-making process is facilitated, with the inherent risks. The contribution of Cognitive Psychology describes the various nomenclatures of heuristics and biases, which will be addressed in the most incident ones in the field of procedural game.

It should be noted that the use of the term 'unconscious' will not be exclusively psychoanalytic, which will broaden understanding, since, according to Callegaro (2011, p. 16), we find literature divided into two basic aspects: on the one hand, psychoanalysts and humanists who use the term unconscious, referring to Freud's concepts; on the other hand, scientists who avoid the term by their connotations, looking for other expressions such as implicit processes (memory neuroscience), subliminal (social psychology), or automatic (cognitive psychology). ${ }^{35}$

As "working memory" is limited, the availability (evocation facility) of our personal experiences may entail shortcuts to the decision. The point is that with it, the logic of reasoning ${ }^{36}$ is often manipulated. The availability heuristic can mean the disregard of the peculiarities of the case, associating a previous and recent decision with a similar hypothesis, with the risk of distorted information either by the press, by stereotypes, or by personal experiences (including unconscious ones) that occur at the moment of the decision $^{37}$. It can operate the cognitive dissonance by the availability of recent decision-making in the pretense of maintaining coherence and avoidance of dissonance ${ }^{38}$, especially when using the fallacy of illusory correlation. ${ }^{39}$ Therefore, the order of depositions, the primacy, or the availability of recent information (evidence) should be evaluated since we remember more easily what is 'fresh' in the memory. Is the order of witnesses/informants worth starting with the best or saving the best for the grand finale? ${ }^{40}$

Therefore, the importance of "Case Theory", given the need to emphasize the uniqueness of the hypothesis in judgment, of its characters. Otherwise, given the association to previous and available cases in memory, often before the narrative of the hypothesis, it's not given the due importance to the contradictory evidence ${ }^{41}$. The same holds true for the hypothesis of errors. This is seen in recent experience in professional activity, the last book read, the lecture attended, or even a pleasant/unpleasant memory ${ }^{42}$. The degree of ease with which similar situations are remembered, of their relevant points, in detail, can make a difference. What is more available becomes easier and there is a tendency to overestimate the standards ${ }^{43}$. Availability can operate not only in relation to the process but also within the context the game is played.

\section{FINAL CONSIDERATIONS}

The complexity of the dynamic and multifactor model in which the decisions in a democracy can be made requires a comprehensive effort to outline the scenarios with its players, rules, rewards, and tactics/strategies that can establish realistically "how" the structure of human interaction mediated by the process, in which Game Theory can be an ally of meaning, is established. 
In addition to the formal reading indicated by the Game Theory, the cognitive environment is opened, with traps, biases, and heuristics, whose domain is relevant for a realistic accommodation of the procedural game environment. Although not all the possibilities of heuristics and biases have been explored ${ }^{44}$, stressing the incidence served as evidence of the complexity in which decision theories need to dialogue. What really matters is to reveal the possible incidence of human factors in the understanding of language games ${ }^{45}$.

\section{ACKNOWLEDGEMENT}

Translated \& edited by American Publishing Services (https://americanpublishingservices.com/).

\section{ENDNOTES}

1. The extended discussion, through the Game Theory applied to Law, was established in previous publications, among them the most recent: Morais da Rosa, A. (2019). Guia do Processo Penal conforme a Teoria dos Jogos. Florianópolis: EMais. Therefore, I will use the term "player" as synonymous with "operator of law", including all those that interact in any decision context, provided with their own "mind map", singular rewards, indicated in the face of coordinates from the specified human interaction.

2. Allard, J., \& Garapon, A. (2006). Os juízes na Mundialização: a nova revolução do Direito. Lisbon: Piaget Institute; Ramires, M. (2016). Diálogo judicial internacional: o uso da jurisprudência estrangeira pela justiça constitucional. Rio de Janeiro: Lumen Juris; Hespanha, A. M. (2005). Cultura Jurídica Européia: síntese de um milênio. Florianópolis: Fundação Boiteux; Dimoulis, D. (2006). O positivismo jurídico: introdução a uma teoria do direito e defesa do pragmatismo jurídico-político. São Paulo: Método; Losano. M. G. (2007). Os Grandes Sistemas Jurídicos. São Paulo: Martins Fontes, 2007. According to Losano (2007, p. 345), the Anglo-American Common Law and continental European law, which now govern the majority of the world's population, tend to approximate: Common Law is undergoing an extension of statutes and consolidations to the detriment of the pure 'judge made law'.

3. Kahneman, D. (2012). Rápido e Devagar: duas formas de pensar. Rio de Janeiro: Objetiva; Kahneman, D., \& Frederick, S. Representativeness Revisited: Attribute Substitution in Intuitive Judgment. In T. Gilovich, D. Griffin, \& D. Kahneman (Eds.), Heuristics and Biases: The Psychology of Intuitive Judgment (pp. 49-81). New York: Cambridge University Press, Wojciechowski, P. B., \& Morais da Rosa, A. (2018). Vieses da Justiça: como as heurísticas e vieses operam nas decisões penais atuação contraintuitiva. Florianópolis: Emodara-EMais.

4. Warat, L. A. (1995). Introdução Geral ao Direito: a epistemologia jurídica da modernidade. Porto Alegre: Sergio Fabris. According to Warat (1995, p. 15), jurists rely on a tangle of intellectual habits that are accepted as truths of principle to conceal the political component of the investigation of truths. Therefore, certain images and beliefs can be canonized to preserve the secret that hides the truths. The world of jurists is a place of secrecy. The representations that integrate it pulverize our understanding of the fact that the history of legal truths is inseparable (so far) from the history of power.

5. Morais da Rosa, A. (2019). Guia do Processo Penal conforme a Teoria dos Jogos. Florianópolis: EMais. When reading the criminal proceeding thru the lens of Game Theory, the proceeding itself is reffered to as a Game and the jurist is therefore interpreted as "player".

6. Atienza, M. (2014). As razões do direito: teoria da argumentação jurídica. Rio de Janeiro: Forense Universitária.

7. Habermas, J. (2010). Direito e Democracia: entre facticidade e validade. Rio de Janeiro: BTU; Britto, C. A. S. (2014). Processo Penal Comunicativo: comunicação processual à luz da filosofia de Jürgen Habermas. Curitiba: Juruá; Günter, K. (2011). Teoria da argumentação no direito e na moral: justificação e aplicação. Rio de Janeiro: Forense.

8. Perelman, C. (2002). Tratado de Argumentação. São Paulo: Martins Fontes.

9. Kay (2011, preface). Kay, J. (2011). Obliquity. New York: The Penguin Press.

10. Casara, R. R. R. (2004). Interpretação Retrospectiva: sociedade brasileira e processo penal. Rio de Janeiro: Lumen Juris.

11. Matlin, M. W. (2004). Psicologia Cognitiva. Rio de Janeiro: LTC. According to Matlin (2004, p. 286-287), in 1979, a man named Lawrence Singleton attacked a young woman who had asked him for a ride in California. He was sentenced to 14 years in prison, but he served eight years - he was released through an early termination of probation, for good behavior. Singleton then moved to his hometown in Florida where 
he lived quietly for about ten years. In 1997, he attacked another woman, who died due to multiple stab wounds. As one can imagine, people were outraged that the authorities in California had released Singleton before he served his time. However, it is worth noting that Singleton had been a model prisoner; according to the information the authorities had, they may have made the right decision. Pay attention to how a retrospective bias is applied here. While reading about Lawrence Singleton, weren't you tempted to conclude that the authorities had been foolish and inconsequential for granting him early termination of probation? Maybe you overestimated their ability to predict that Singleton would hurt someone again.

12. Morais da Rosa, A. (2006). Decisão Penal: a bricolagem de significantes. Rio de Janeiro: Lumen Juris.

13. Streck, L. L. (2012). Verdade e Consenso. São Paulo: Saraiva; Faccini Neto, O. (2011). Elementos de uma Teoria da Decisão Judicial: hermenêutica, Constituição e respostas corretas em Direito. Porto Alegre: Livraria do Advogado.

14. Smith, A. (1983). A riqueza das nações: investigação sobre sua natureza e suas causas. São Paulo: Abril Cultural.

15. Morais da Rosa, A., \& Kalhed Jr., S. H. (2018). In dubio pro Hell: profanando o sistema penal. (pp. 85-98). Florianópolis: EMais.

16. Davis, M. D. (1973). Teoria dos Jogos: uma introdução não-técnica. São Paulo: Cultrix. According to Davis (1973, p. 74), the story of each one - the success achieved so far in the game - influences the attitude towards risk.

17. Walton, D. N. (2012). Lógica Informal. São Paulo: Martins Fontes. To Walton (2012, p. 33), it is necessary to recognize those critical points in which dialogue is no longer rational or moves away from a better line of argumentation.

18. Retondar, J. J. M. (2007). Teoria do Jogo. Petrópolis: Vozes. To Retondar (2007, p. 15-16), the game becomes a dangerous occupation for the Christian life, insofar as it can detract from the behavior of the individual due to its absorbing and engaging character. In this case, it is not only the game, but the excess that it can provoke is what becomes harmful from the point of view of Christian morality. The game, as one of the passions that occupy the soul, distorts the necessary attention and observance of the prudent man and of faith.

19. Duflo, C. (1990). O jogo: de Pascal a Schiller. Porto Alegre: Artmed; Caillois, R. (1986). Los juegos y los hombres: la máscara y el vértigo. México: Fondo de Cultura Económica. It is important to highlight the typology presented by Caillois : (a) agon (competition - in which merit itself, in a regulated competition, will be the foundation of triumph - sports); (b) ilinx (the quest for vertigo - bets, lotteries, casinos, etc.), (c) mimicry (simulacrum - taste for an alien figure - theater, cinema, carnival, and artist cult); and, (d) alea (luck - in which the passivity of waiting and the anxiety of fate prevail - mountaineering, skiing, extreme sports).

20. Duflo, C. (1990). O jogo: de Pascal a Schiller. Porto Alegre: Artmed.

21. Gadamer, H. G. (1985). A atualidade do belo. A arte como jogo, símbolo e festa. (pp. 37). Rio de Janeiro: Tempo Brasileiro.

22. Baird, D. G., Gertner, R. H., \& Pickler, R. C. (1994). Game Theory and the Law. Cambridge: Harvard University Press; Robles, G. (2011). As regras do direito e as regras dos jogos: ensaio sobre a teoria analítica do direito. São Paulo: Noeses; Gibbons, R. (1992). Games theory. New Jersey: Princeton University; Heidegger, M. (2008). Introdução à filosofia. São Paulo: Martins Fontes; Binmore, K. (2011). Teoría de Juegos: una breve introducción. Madrid: Alianza; Sierralta Ríos, A. (2017). Negociação e Teoria dos Jogos. São Paulo: RT; Abreu, C. P. de. (2014). Estratégia Processual: De uma visão bélica para uma perspectiva meramente processual. Coimbra: Almedina; Pletsch, N. R. (2007). Formação da Prova no Jogo Processual Penal. São Paulo: IBCCRIM; Gonçalves, J. (2016). Acesso à Justiça e Teoria dos Jogos: da lógica competitiva do processo civil à estratégia cooperativa da mediação. Florianópolis: Empório do Direito; Winnicott, D. W. (2013). Realidad y Juego. Barcelona: Gedisa; Rufián Lizana, A. (2017). La búsqueda del equilibrio en la teoría de juegos. Madrid: RBA.

23. Calamandrei, P. (2002). O processo como jogo. Revista de Direito Processual Civil, 23, 192.

24. This chapter is due to the dialogues with Laércio A. Becker. Becker, L. A. (2012). Qual é o jogo do processo? Porto Alegre: Sérgio Fabris. The metaphor of chess in game theory applied to the criminal process is insufficient because the game of chess is of full information, in the face of the pieces present on the board, without the past and the future, because it manifests itself in the present. It is also known that Dworkin criticizes the interpretative gap of the game of chess as a metaphor of law. See: Davis, M. D. (1973). Teoria dos Jogos: uma introdução não-técnica. (pp. 25-28). São Paulo: Cultrix; Dworkin, R. (1999). O Império do Direito. São Paulo: Martins Fontes; Macedo Junior, R. P. (2013). Do xadrez à cortesia. São Paulo: Saraiva; Cattoni De Oliveira, M. A. (2001). Direito Processual Constitucional. Belo Horizonte: Del Rey.

25. Robles, G. (2010). La Justicia en los juegos. Madrid: Trotta. 
26. Becker, L. A. (2012). Qual é o jogo do processo? Porto Alegre: Sérgio Fabris.

27. Davis, M. D. (1973). Teoria dos Jogos: uma introdução não-técnica. São Paulo: Cultrix. According to Davis (1973, p. 117-118), he begins by presuming that two parties are negotiating a contract. For reasons of convenience and without loss of generality, Nash assumes that a failure in understanding - no agreement is made, no sale - will have zero utility for both players. He then chooses a singular, arbitrated result, removing it from the set of agreements that the participants can reach, selecting the result in which the product of the players' profits is maximum. This scheme has four properties of great coexistence that, in Nash's point of view, justify its use. And it is the only scheme to have such properties that are: 1 . The arbitrated result must be independent of the utility function. Any arbitrated result must clearly depend on the preferences of the players and these preferences are expressed through a utility function. However, as we have seen previously, there are many utility functions to choose from. Since the choice of a utility function is entirely arbitrary, it becomes reasonable to require that the arbitrated result does not depend on the utility function chosen. 2 . The arbitrated result must be Pareto optimality. Nash considered it desirable that the arbitrated result should be confused with the Pareto optimality; that is, there should be no other result in which both players simultaneously achieve more under such conditions. 3 . The arbitrated result must be independent of irrelevant alternatives. Suppose there are two games A and B in which all the results of A are also results of B. If the arbitrated result of B is also a result of A, that result must be the same as that arbitrated in A. In other words, the result arbitrated in a game remains the arbitrated result, even when other results are eliminated as possible agreements. 4. In a symmetrical game, the arbitrated result has the same utility for both participants. Suppose that players in a negotiation game have symmetrical roles; that is, there is a result with utility $\mathrm{x}$ for one of the players and utility y for the other. In these circumstances, there must also be a result that has utility y for the first player and $\mathrm{x}$ for the second player. In such a game, the arbitrated result should be equally useful for both players.

28. Warat, L. A. (2011). A Rua Grita Dionísio. Rio de Janeiro: Lumen Juris.

29. Wojciechowski, P. B., \& Morais da Rosa, A. (2018). Vieses da Justiça: como as heurísticas e vieses operam nas decisões penais e a atuação contraintuitiva. Florianópolis: EMais.

30. Michel-Kerjan, E., \& Slovic, P. (Eds.). (2010). A economia irracional: como tomar as decisões certas em tempos de incerteza. Rio de Janeiro: Elsevier. According to Michel-Kerjan (2010, p. 5), as human beings, we have intuitive and analytical thinking skills that work beautifully, most of the time, that help us to navigate through life and achieve our goals as individuals or as a group. But sometimes our faculties of rational thinking fail.

31. Sternberg, R. J. (2012). Psicologia Cognitiva. São Paulo: Cengage Learning. To Sternberg (2012, p. 442), regarding the overvaluation that a person makes of his/her own abilities, in general, people tend to overestimate the accuracy of their judgments. Why do people show overconfidence? One reason is that people may not realize how little they know. A second reason is that they can understand what they are assuming when they use the knowledge they possess. A third reason may be that they do not know that their information is based on unreliable sources. The reason we tend to manifest overconfidence in our judgments is not clear. A simple explanation is that we prefer not to think about the possibility of being wrong.

32. Wojciechowski, P. B., \& Morais da Rosa, A. (2018). Vieses da Justiça: como as heurísticas e vieses operam nas decisões penais e a atuação contraintuitiva. Florianópolis: EMais; Nunes, D., Lud, N., \& Pedron, F. Q. (2018). Desconfiando da Imparcialidade dos Sujeitos Processuais: um estudo sobre os vieses cognitivos, a mitigação de seus efeitos e o debiasing. Salvador: JusPodivm; Costa, E. J. da F. (2018). Levando a imparcialidade a sério: proposta de um modelo interseccional entre direito processual, economia e psicologia. Salvador: JusPodivm; Goulart, B. B. Análise Econômica da Litigância: entre o modelo da escolha racional e a economia comportamental (Master's thesis). Universidade Federal de Santa Catarina, Florianópolis, Santa Catarina, Brazil; and my book written with Gisele Tobler. The international bibliography is, in addition, abundant on the subject; Abiko, P. Y. (2018). Vieses da Justiça e Atuação Contraintuitiva. Retrieved on July 5, 2019 from https://canalcienciascriminais.com.br/vieses-justica/

33. Mackaay, E., \& Rousseau, S. (2015). Análise Econômica do Direito. São Paulo: Atlas. Mackaay \& Rousseau (2015, p. 35) point out that psychological research shows that humans judge complex situations imperfectly. Here, the spirit, once again, tends to simplify them by means of heuristics to bring them to the level where they can be approached with the ordinary mind faculties that we have at present. According to the authors, Tversky and Kahneman propose, under the name of prospect theory, to represent the decision in two stages. The first is to find a frame for the problem and frame it (framing and editing); the second step is evaluation. For what we are interested in, it is the first stage that intervenes in the rules: the representation obtained is a 
function of the way in which the problem is presented to the decision maker rather than by the norms, habits, and care adopted. The representation determines the aspects of the problem to be considered.

34. Sternberg, R. J. (2012). Psicologia Cognitiva. São Paulo: Cengage Learning. To Sternberg (2012, p. 25), one can perceive, learn, remember, reason, and solve problems with great precision. This occurs even with a lot of stimuli. Any stimulus can divert the individual from the proper processing of information. However, the same processes that lead us to perceive, remember, and reason accurately in most situations can also lead us to error. Our memories and reasoning, for example, are susceptible to certain well-identified systematic errors. For example, as one realizes how much he/she has learned about heuristic availability, the tendency is to overvalue the information that is already available, and this occurs even when the information is not entirely relevant to the problem in question.

35. Callegaro, M. M. (2011). O novo inconsciente. Porto Alegre: Artmed.

36. Mackaay, E., \& Rousseau, S. (2015). Análise Econômica do Direito. São Paulo: Atlas. Mackaay \& Rousseau (2015, p. 35) affirm that we do not properly evaluate small probabilities. They are ignored. It would not be justified to take them more seriously than the 'objective' risk. The overestimation of risk appears especially when we realize a living picture of danger. Not being able to judge the odds directly, the human spirit simplifies the problem by appealing to the availability heuristic, which will make us decide according to the example that is still fresh in the mind (spirit). When a plane crashes, some people stop booking flights in which they should board during the days right after the crash. We are also, and often, prisoners of the gambler's ruin. If during the month of July it rains for three days, but it has rained five days since the beginning of the month (July), we believe that the rest of the month will necessarily be of good weather.

37. Sternberg, R. J. (2012). Psicologia Cognitiva. São Paulo: Cengage Learning. According to Sternberg (2012, p. 440), examples of distorted coverage could be the sensationalist tabloid coverage of the press, extensive advertising, the recent character of an unusual occurrence or personal bias. Generally, we make decisions in which the most common cases are the most relevant and valuable. In such cases, the availability heuristic often represents a convenient shortcut with few burdens. However, when particular cases are best remembered for distortions (for example, their view of their own behavior compared to that of other people), the availability heuristic can lead to decisions that are unfortunate.

38. Festinger, L. (1975). Teoria da dissonância cognitiva. Rio de Janeiro: Zahar; Schünemann, B. (2013). Estudos de direito penal, direito processual penal e filosofia do direito. São Paulo: Marcial Pons; Rodrigues, A., Assmar, E. M. L, \& Jablonski, B. (2010). Psicologia social. Petrópolis: Vozes; Goldstein, J. H. (1983). Psicologia social. Rio de Janeiro: Guanabara Dois; Álvaro, J. L., \& Garrido, A. (2006). Psicologia social: perspectivas psicológicas e sociológicas. São Paulo: McGraw-Hill; Berkowitz, L. (1980). Psicologia social. Rio de Janeiro: Interamericana; Lima, L. P. de. (2004). Atitudes: estrutura e mudança. In J. Vala, \& M. B. Monteiro (Eds.), Psicologia social. Lisboa: Fundação Calouste Gulbenkian; Ritter, R. (2017). Imparcialidade no processo penal: reflexões a partir da teoria da dissonância cognitiva. Florianópolis: Empório do Direito.

39. Matlin, M. W. (2004). Psicologia Cognitiva. Rio de Janeiro: LTC. To Matlin (2004, p. 276), a correlation is a statistical relationship between two variables, even if there is no real evidence of that relationship. Thus, there is an illusory correlation when people believe that two variables are statistically related, even if there is no real evidence of this relationship. According to several studies, we often believe that a certain group of people tend to have certain types of characteristics, although an exact classification shows that the relationship is not statistically significant. Think of some examples of stereotypes that emerge from illusory correlations. These may or may not have a basis in fact; may even have much less basis than is commonly believed. For instance, the following illusionary correlations: women are not good at math, blond women are not very intelligent, male and female homosexuals have psychological problems, and so on. According to an important current approach, our stereotypes are influenced by cognitive processes, such as availability.

40. Walton, D. N. (2012). Lógica Informal. São Paulo: Martins Fontes. According to Walton (2012, p. 81-82), every argument presupposes a context of dialogue in which there is a question, or perhaps several questions, under discussion. To the author, in practice, one of the major problems in assessing a realistic argument is that the debaters may not even be clear about what they are discussing.

41. Sternberg, R. J. (2012). Psicologia Cognitiva. São Paulo: Cengage Learning. According to Sternberg (2012, p. 440), one of the factors that lead to greater availability of an event is actually the higher frequency of the event.

42. Matlin, M. W. (2004). Psicologia Cognitiva. Rio de Janeiro: LTC. Matlin (2004, p. 274-275) points out that a paper in the New England Journal of Medicine highlights how doctors' decisions may be influenced by the recency effect. According to the author, the paper reports the case of a medical doctor who was reluctant to recommend a particular clinical procedure because he had previously seen one of his patients, who had 
undergone such a procedure, develop a serious neurological disorder. The authors of the paper said that remembering a patient who has suffered a complication is an example of the heuristic of availability. Matlin (2004) states that other research suggests implications for clinical psychology. As reported by Matlin, MacLeod and Campbell (1992) found that when people were encouraged to remember pleasant events in the past, they evaluated those events as more probable to happen in their future. On the contrary, when they were encouraged to remember unpleasant events, they considered them less probable.

43. Marinho, R. (2011). Prática na Teoria: aplicações da teoria dos jogos e da evolução aos negócios. São Paulo: Saraiva. As stated by Marinho (2011, p. 268), the disproportional impact of recent events on trials is so powerful that even individuals who are aware of this fact have difficulty avoiding it. It takes a lot of mental effort not to make the wrong decision because of the influences of recent events.

44. Nunes, D., Lud, N., \& Pedron, F. Q. (2018). Desconfiando da Imparcialidade dos Sujeitos Processuais: um estudo sobre os vieses cognitivos, a mitigação de seus efeitos e o debiasing. Salvador: JusPodivm; Costa, E. J. da F. (2018). Levando a imparcialidade a sério: proposta de um modelo interseccional entre direito processual, economia e psicologia. Salvador: JusPodivm. See also https://en.m.wikipedia.org/wiki/List_of_cognitive_biases

45. Wittgenstein, L. (1999). Investigações filosóficas. São Paulo: Nova.

\section{REFERENCES}

Abiko, P.Y. (2018). Vieses da Justiça e Atuação Contraintuitiva. Retrieved July 5, 2019, from https://canalcienciascriminais.com.br/vieses-justica/

Allard, J., \& Garapon, A. (2006). Os juizes na Mundialização: A nova revolução do Direito. Lisbon: Piaget Institute.

Álvaro, J.L., \& Garrido, A. (2006). Psicologia social: Perspectivas psicológicas e sociológicas. São Paulo: McGraw-Hill.

Atienza, M. (2014). As razões do direito: Teoria da argumentação jurídica. Rio de Janeiro: Forense Universitária.

Baird, D.G., Gertner, R.H., \& Pickler, R.C. (1994). Game Theory and the Law. Cambridge: Harvard University Press.

Becker, L.A. (2012). Qual é o jogo do processo? Porto Alegre: Sérgio Fabris.

Berkowitz, L. (1980). Psicologia social. Rio de Janeiro: Interamericana.

Binmore, K. (2011). Teoría de Juegos: Una breve introducción. Madrid: Alianza.

Britto, C.A.S. (2014). Processo Penal Comunicativo: Comunicação processual à luz da filosofia de Jürgen Habermas. Curitiba: Juruá.

Caillois, R. (1986). Los juegos y los hombres: La máscara y el vértigo. México: Fondo de Cultura Económica.

Calamandrei, P. (2002). O processo como jogo. Revista de Direito Processual Civil, 23, 192.

Callegaro, M.M. (2011). O novo inconsciente. Porto Alegre: Artmed.

Casara, R.R.R. (2004). Interpretação Retrospectiva: Sociedade brasileira e processo penal. Rio de Janeiro: Lumen Juris.

Cattoni De Oliveira, M.A. (2001). Direito Processual Constitucional. Belo Horizonte: Del Rey.

da Costa, E.J. (2018). Levando a imparcialidade a sério: Proposta de um modelo interseccional entre direito processual, economia e psicologia. Salvador: JusPodivm.

Davis, M.D. (1973). Teoria dos Jogos: Uma introdução não-técnica. São Paulo: Cultrix.

de Abreu, C.P. (2014). Estratégia Processual: De uma visão bélica para uma perspectiva meramente processual. Coimbra: Almedina.

de Lima, L.P. (2004). Atitudes: Estrutura e mudança. In J. Vala \& M.B. Monteiro (Eds.), Psicologia social. Lisboa: Fundação Calouste Gulbenkian.

Dimoulis, D. (2006). O positivismo jurídico: Introdução a uma teoria do direito e defesa do pragmatismo jurídico-político. São Paulo: Método.

Duflo, C. (1990). O jogo: De Pascal a Schiller. Porto Alegre: Artmed.

Dworkin, R. (1999). O Império do Direito. São Paulo: Martins Fontes. 
Faccini Neto, O. (2011). Elementos de uma Teoria da Decisão Judicial: Hermenêutica, Constituição e respostas corretas em Direito. Porto Alegre: Livraria do Advogado.

Festinger, L. (1975). Teoria da dissonância cognitiva. Rio de Janeiro: Zahar.

Gadamer, H.G. (1985). A atualidade do belo. A arte como jogo, símbolo e festa. Rio de Janeiro: Tempo Brasileiro.

Gibbons, R. (1992). Games theory. New Jersey: Princeton University.

Goldstein, J.H. (1983). Psicologia social. Rio de Janeiro: Guanabara Dois.

Gonçalves, J. (2016). Acesso à Justiça e Teoria dos Jogos: Da lógica competitiva do processo civil à estratégia cooperativa da mediação. Florianópolis: Empório do Direito.

Goulart, B.B. (n.d.). Análise Econômica da Litigância: Entre o modelo da escolha racional e a economia comportamental (Master's thesis). Universidade Federal de Santa Catarina, Florianópolis, Santa Catarina, Brazil.

Günter, K. (2011). Teoria da argumentação no direito e na moral: Justificação e aplicação. Rio de Janeiro: Forense.

Habermas, J. (2010). Direito e Democracia: Entre facticidade e validade. Rio de Janeiro: BTU.

Heidegger, M. (2008). Introdução à filosofia. São Paulo: Martins Fontes.

Hespanha, A.M. (2005). Cultura Jurídica Européia: Sintese de um milênio. Florianópolis: Fundação Boiteux.

Kahneman, D. (2012). Rápido e Devagar: Duas formas de pensar. Rio de Janeiro: Objetiva.

Kahneman, D., \& Frederick, S. (2013). Representativeness Revisited: Attribute Substitution in Intuitive Judgment. In T. Gilovich, D. Griffin, \& D. Kahneman (Eds.), Heuristics and Biases: The Psychology of Intuitive Judgment (pp. 49-81). New York: Cambridge University Press.

Kay, J. (2011). Obliquity. New York: The Penguin Press.

Losano, M.G. (2007). Os Grandes Sistemas Jurídicos. São Paulo: Martins Fontes.

Macedo Junior, R.P. (2013). Do xadrez à cortesia. São Paulo: Saraiva.

Mackaay, E., \& Rousseau, S. (2015). Análise Econômica do Direito. São Paulo: Atlas.

Marinho, R. (2011). Prática na Teoria: Aplicações da teoria dos jogos e da evolução aos negócios. São Paulo: Saraiva.

Matlin, M.W. (2004). Psicologia Cognitiva. Rio de Janeiro: LTC.

Michel-Kerjan, E., \& Slovic, P. (Eds.). (2010). A economia irracional: Como tomar as decisões certas em tempos de incerteza. Rio de Janeiro: Elsevier.

Morais da Rosa, A. (2006). Decisão Penal: A bricolagem de significantes. Rio de Janeiro: Lumen Juris.

Morais da Rosa, A. (2019). Guia do Processo Penal conforme a Teoria dos Jogos. Florianópolis: EMais.

Morais da Rosa, A., \& Kalhed, S.H., Jr. (2018). In Dubio pro Hell: Profanando o sistema penal (pp. 8598). Florianópolis: EMais.

Nunes, D., Lud, N., \& Pedron, F.Q. (2018). Desconfiando da Imparcialidade dos Sujeitos Processuais: Um estudo sobre os vieses cognitivos, a mitigação de seus efeitos e o debiasing. Salvador: JusPodivm.

Perelman, C. (2002). Tratado de Argumentação. São Paulo: Martins Fontes.

Pletsch, N.R. (2007). Formação da Prova no Jogo Processual Penal. São Paulo: IBCCRIM.

Ramires, M. (2016). Diálogo judicial internacional: O uso da jurisprudência estrangeira pela justiça constitucional. Rio de Janeiro: Lumen Juris.

Retondar, J.J.M. (2007). Teoria do Jogo. Petrópolis: Vozes.

Ritter, R. (2017). Imparcialidade no processo penal: Reflexões a partir da teoria da dissonância cognitiva. Florianópolis: Empório do Direito.

Robles, G. (2010). La Justicia en los juegos. Madrid: Trotta.

Robles, G. (2011). As regras do direito e as regras dos jogos: Ensaio sobre a teoria analítica do direito. São Paulo: Noeses.

Rodrigues, A., Assmar, E.M.L., \& Jablonski, B. (2010). Psicologia social. Petrópolis: Vozes.

Rufián Lizana, A. (2017). La búsqueda del equilibrio en la teoría de juegos. Madrid: RBA. 
Schünemann, B. (2013). Estudos de direito penal, direito processual penal e filosofia do direito. São Paulo: Marcial Pons.

Sierralta Ríos, A. (2017). Negociação e Teoria dos Jogos. São Paulo: RT.

Smith, A. (1983). A riqueza das nações: Investigação sobre sua natureza e suas causas. São Paulo: Abril Cultural.

Staffen, M.R. (2014). Judicial selfie? Não, obrigado! Em defesa da multiplicidade do discurso [jurídico]. Novos Estudos Jurídicos, 19(3), 1045-1069.

Sternberg, R.J. (2012). Psicologia Cognitiva. São Paulo: Cengage Learning.

Streck, L.L. (2012). Verdade e Consenso. São Paulo: Saraiva.

Walton, D.N. (2012). Lógica Informal. São Paulo: Martins Fontes.

Warat, L.A. (1995). Introdução Geral ao Direito: A epistemologia jurídica da modernidade. Porto Alegre: Sergio Fabris.

Warat, L.A. (2011). A Rua Grita Dionísio. Rio de Janeiro: Lumen Juris.

Winnicott, D.W. (2013). Realidad y Juego. Barcelona: Gedisa.

Wojciechowski, P.B., \& Morais da Rosa, A. (2018). Vieses da Justiça: Como as heurísticas e vieses operam nas decisões penais atuação contraintuitiva. Florianópolis: Emodara-EMais.

Wojciechowski, P.B., \& Morais da Rosa, A. (2019). Vieses da Justiça: Como as heurísticas e vieses operam nas decisões penais e a atuação contraintuitiva. Florianópolis: EMais. 